4. Ноев В.Н. Проблемы и задачи энергосбережения в Республике Саха (Якутия) // Энергосбережение. №4-2003.

5. Об энергосбережении и о повышении энергетической эффективности, и о внесении изменений в отдельные законодательные акты Российской Федерации: Федеральный закон от 23.11.2009 года №261 // Собрание законодательств РФ. - 2009. №48. - ст.5711.

6. ЛигунЛ.Е. Автоматизированная система диспетчерского управления жилым комплексом // Журнал «АВОК» №3-2005.

7. КовальчукВ.В. Об оптимизации подходов к энергосбережению // Журнал «АВОК» №1-2009.

\title{
Теплоснабжение в Республике Саха (Якутия): особенности и векторы развития
}

\author{
Старостина А.Е., ведущий инженер, \\ Павлов Н.В., научный сотрудник, \\ Институт физико-технических проблем Севера \\ им. В.П. Ларионова СО РАН, г. Якутск, \\ E-mail: pavlov_nv@iptpn.ysn.ru
}

Теплоснабжение потребителей имеет высокую экономическую и социальную значимостью. При этом суровые климатические условия накладывают повышенные требования к надежности и экономичности систем теплоснабжения [1]. На рисунке отображена существующая на данный момент картина отображающая теплопотребление в РС(Я) на душу населения (рисунок 1). Высокое теплопотребление отмечается в северной группе районов, из 14 районов в 8 теплопотребление на душу населения выше 14 Гкал/чел, в остальных районах свыше 11 Гкал/ч, исключая ЭвеноБытантайский национальный улус, в котором теплопотребление составило 9,3 Гкал/чел. В центральной, южной и западной группе районов характерно низкое теплопотребление на душу населения, из 21 районов в 15 теплопотребление ниже 10 Гкал/чел. Исключение составляют крупные промышленные районы Мирнинский и Нерюнгринский, в которых теплопотребление превышает 17 Гкал/чел.

Система теплоснабжения Республики характеризуется высокой степенью износа оборудования источников тепловой энергии и тепловых сетей, низкой эффективностью и надежностью, неудовлетворительным уровнем комфорта в зданиях, высоких потерях тепловой энергии, сложностью доставки топлива, ненормативными потерями топлива при транспортировке, низкой надежностью теплоснабжения, а также низкой степенью использования установленной мощности, что показывает, с одной стороны, высокую степень резервирования источников теплоснабжения, а с другой, - неэффективность использования оборудования $[2,3,4]$. 


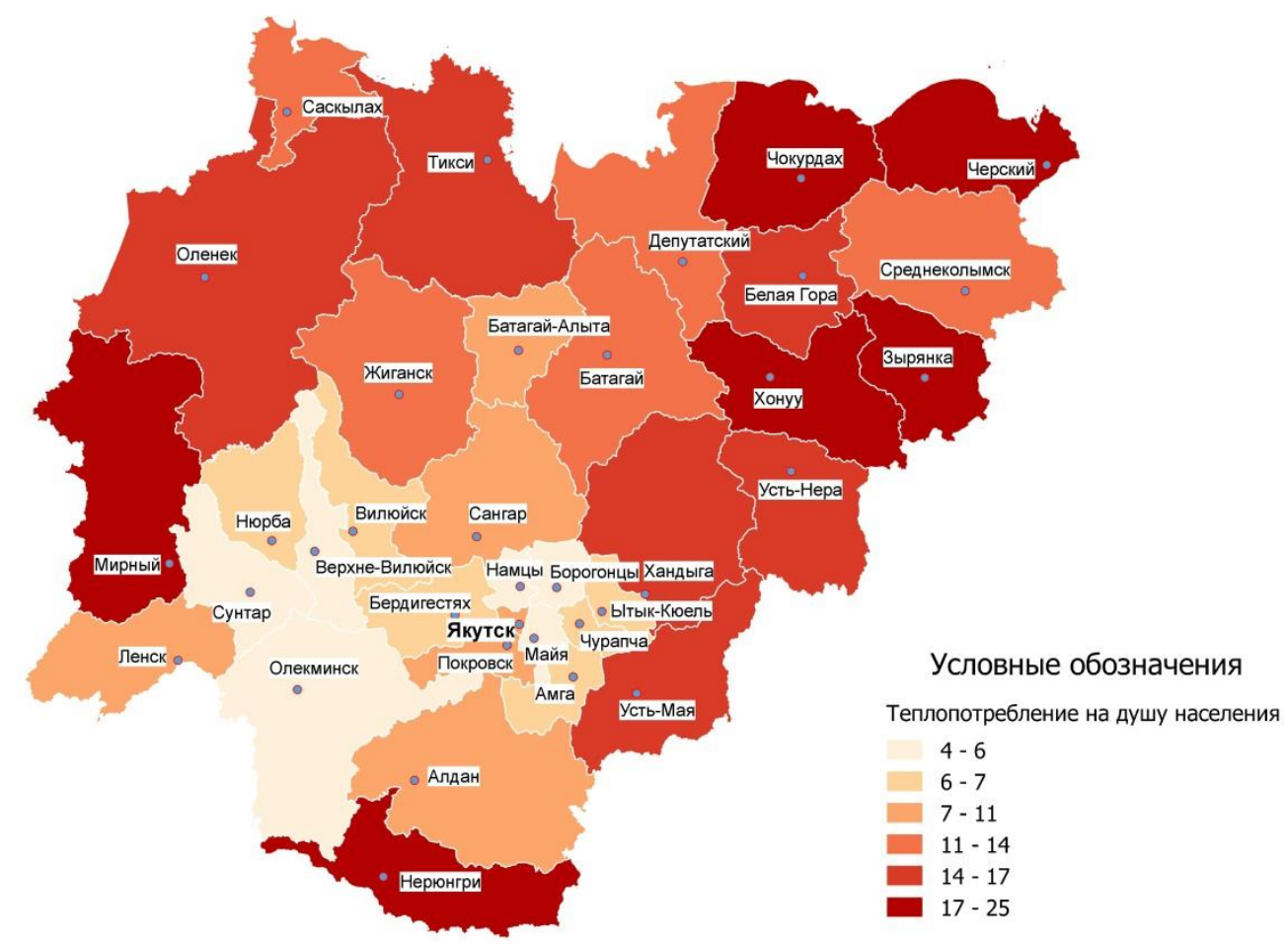

Рис. 1. Теплопотребление на душу населения в Республике Саха (Якутия)

Протяженность тепловых сетей в Республике в 2015 г. составила 3,91 тыс. км, причем 82 \% из них распределительные сети диаметром до 200 мм. Согласно статистическим данным износ тепловых сетей в 2015 г. не превысил 24,9\%, в действительности фактический уровень износа значительно выше. Основная доля эксплуатируемых тепловых сетей (около 65\%) принадлежит АО «Теплоэнергосервис» и ГУП «ЖКХ РС (Я)», обеспечивающим теплоснабжение потребителей в различных районах Республики. По данным ГУП «ЖКХ РС (Я)», в ведении которого находится более трети тепловых сетей Республики, их износ составляет 57\%.

Прокладка тепловых трасс во многих районах Республики надземная, тепловая изоляция трубопроводов выполнена минватой, теплоизоляционными полотнами ПСХТ. Изоляция на некоторых участках находится в неудовлетворительном состоянии, что приводит к дополнительным тепловым потерям в сетях. Количество участков тепловых трасс, не утепленных надлежащим образом, составляет по различным оценкам 40 до $60 \%$. Деревянные короба, в которые уложены некоторые трубопроводы с изоляцией из древесной стружки, подвергаются воздействию атмосферных осадков, что является негативным фактором.

В связи с отсутствием достоверной информации о размещении источников теплоснабжения на промплощадках остается невозможным оценить примерную протяженность тепловых сетей в период до 2020 г. Согласно принятым инвестиционным программам развития основных предприятий коммунального сектора в период с 2016 по 2020 гг. строительство новых тепловых сетей не превысит 40 км, модернизация существующих тепловых сетей - 511,0 км. В соответствии с представленной динамикой замены тепловых сетей уровень износа останется практически неизменным. 
К 2030 г. рост теплопотребления в г. Якутске составит около 61,6 \%, при этом он будет обеспечиваться за счет увеличения жилищного (рост около 70\%) и общественного фонда, а также ростом численности населения [4]. Значительный объем ввода жилой площади в городе планируется в зоне теплоснабжения ЯГРЭС-1. Для покрытия дефицита тепловой мощности, в связи с предполагаемым приростом нагрузки и выводом мощностей ЯГРЭС-1, к 2017 г. необходим ввод дополнительной тепловой мощности в объеме 300 Гкал/ч в узле ЯГРЭС-1 (пиковой котельной).

Ввод в эксплуатацию мощностей ЯГРЭС-2 планируется осуществить в два этапа, при этом в 2017 г. предполагается ввод 469 Гкал/ч., а в 2019 г. тепловая мощность станции составит 574 Гкал/ч.

Тепловую мощность ЯГРЭС-2 составят семь водогрейных котлов-утилизаторов (КУВ) единичной мощностью 42,9 Гкал/ч., а также три водогрейных пиковых котла единичной мощностью 100 Гкал/ч.

При увеличении тепловой мощности вновь вводимой Якутской ГРЭС-2 появляется возможность закрытия неэффективных котельных в зоне обслуживания станции. В связи с размещением Якутской ГРЭС-2 отдаленно от существующих электростанций предполагается строительство магистральных тепловых сетей.

Строительство мини-ТЭЦ на угле является альтернативой для децентрализованных районов, расположенных вдоль водных путей, что сокращает затраты на доставку топлива и, тем самым, себестоимость производства электрической и тепловой энергии [5]. В настоящее время ведется строительство мини-ТЭЦ на угле в п. Зырянка. В 2015 г. объявлен аукцион по общестроительным работам главного корпуса и топливоподачи. Ввод в эксплуатацию этой станции установленной тепловой мощностью 25 Гкал/ч предполагается в 2017 г.

Наличие природного газа в топливном балансе Республики предполагает возможность строительства газотурбинных станций или переоборудование в станции котельных путем газотурбинной надстройки. Строительство ГТУ-ТЭЦ может быть целесообразным в крупных поселках, расположенных вдоль трассы газопровода, в электроизолированных районах. Кроме того, можно рассмотреть сооружение распределенной генерации энергии у конечных потребителей распределительных электрических сетей для повышения надежности энергоснабжения. Целесообразность переоборудования котельных в ГТУ-ТЭЦ требует детальной проработки, а также будет зависеть от удаленности населенного пункта от газопровода, включения поселка в программу газификации, наличия электрических сетей, существующих электрических и тепловых нагрузок потребителей. В рассматриваемый период на территории Республики планируется разработка новых и расширение добычных возможностей существующих нефтегазовых месторождений. В связи с этим потребуется строительство и расширение крупных источников энергоснабжения на Чаяндинском и Среднеботуобинском НГКМ.

В период до 2020 г. при разработке Эльгинского угольного месторождения будут введены крупные объекты энергоснабжения. Проектом освоения месторождения для обеспечения надежного теплоснабжения промышленного производства планируется ввод в эксплуатацию котельной. В котельной устанавливаются 3 водогрейных котла теплопроизводительностью по 30 Гкал/ч каждый и 2 паровых котла теплопроизводительностью по 15 т/ч пара каждый. Суммарная установленная тепловая мощность составит 107 Гкал/ч. 
Расширение существующих и разработка новых месторождений полезных ископаемых потребует также ввода в эксплуатацию новых промышленных котельных. В Южно-Якутском энергорайоне в рассматриваемый период планируется развитие крупных промышленных производств в связи с расположением в непосредственной близости угольных разрезов, теплоснабжение данных промышленных объектов предполагается осуществлять на базе угольных котельных. Теплоснабжение промышленных объектов, расположенных в децентрализованной зоне электроснабжения, будет обеспечено за счет установки котлов-утилизаторов на дизельные электростанции. Это связано с отдаленным расположением данных промышленных объектов, а также со сравнительно невысоким уровнем теплопотребления данного вида промышленных производств.

Основные специфические особенности в сфере теплоснабжения Республики Саха (Якутия):

1. Неудовлетворительный технический уровень, обусловленный недостаточной оснащенностью автоматикой, системами учета и регулирования. Устаревшие технические решения не позволяют эффективно транспортировать и использовать тепловую энергию, что приводит: к огромным перерасходам топлива и энергии; частым авариям; чрезмерно высоким издержкам в системах теплоснабжения.

2. Низкий уровень оснащенности централизованным теплоснабжением. В большинстве районов отсутствует возможность по предоставлению услуг централизованного теплоснабжения, водоснабжения и водоотведения, что негативно отражается на качестве жизни населения [1].

3. Высокая степень износа жилищного фонда. Удельный расход тепловой энергии на отопление жилых зданий характеризуется широким диапазоном разброса значений показателя. Высокий уровень расхода тепла связан со значительным износом жилого фонда. Республика входит в число регионов Российской Федерации с наибольшей удельной долей ветхого и аварийного жилья - 16,6 \%. Одной из причин этого является то, что почти две трети жилищного фонда республики составляют деревянные дома (около $60 \%$ от общей площади).

4. Значительный износ оборудования и тепловых сетей в связи с несвоевременным их ремонтом и заменой. Потери в тепловых сетях продолжают возрастать, в среднем по Республике Саха (Якутия) в 2015 г. они составили 24,9 \%, в ряде районов Республики уровень потерь достигает порядка 40 \% (Алданский, УстьЯнский и т.д.). Все это свидетельствует о том, что теплосетевое хозяйство Республики требует особого внимания и значительных капиталовложений в модернизацию существующих тепловых сетей и в строительство новых теплотрасс от новых источников теплоснабжения.

5. Рост теплопотребления будет связан с развитием и расширением существующих промышленных производств, освоением и разработкой новых месторождений и ростом ввода жилья в населенных пунктах Республики (прежде всего в г. Якутске).

\section{Список литературы:}

1. Старостина А.Е., Павлов Н.В. Современное состояние и основные проблемы теплоэнергетики Республики Саха (Якутия) // Материалы XVII Всероссийской научнопрактической конференции молодых ученых, аспирантов и студентов, с 
международным участием в г. Нерюнгри, посвященной 60-летию со дня образования Якутского государственного университета (СВФУ). 2016. Секции 1-3. с.156-159.

2. Энергетическая стратегия Республики Саха (Якутия) на период до 2030 г. Якутск-Иркутск: Медиа-холдинг «Якутия», 2010. - 328 с.

3. Стратегия комплексного развития жилищно-коммунального хозяйства Республики Саха (Якутия) на период до 2030 года.

4. Схема теплоснабжения городского округа «город Якутск». Актуализация на 2016 г.

5. Перспективы развития малой теплофикации в Республике Саха (Якутия) / А.Н. Кузьмин, Е.Ю. Михеева, Н.В. Павлов. - Новосибирск: Изд-во СО РАН, 2013 - 101 c. 